\title{
The gas fuel market in Poland and the costs of final heat generated in a local boiler house
}

AbStRact: About 55\% of over 14 million Polish households live in multi-family buildings. Cooperative or housing association buildings have a large share in this group. The heat is supplied from the district heating network or from local sources. With respect to facilities fed from gas boiler rooms, the signing and execution of fuel supply contracts is required. From October 1, 2017, the obligation to submit tariffs for gas trading set for all final customers (except for individual gas consumers in households) for approval to the President of the Energy Regulatory Office was lifted. Decisions regarding the choice of the supplier and the content of the concluded contract are made by the authorized bodies of the cooperative or housing association. The consequences of such decisions are borne by the owners and users of residential premises. Ensuring the continuity of a contract for the supply of gaseous fuel essentially comes down to establishing prices and rates in force for a given period. The right decision on the moment of signing the contract or the amendment, termination of the existing contract and signing a new one, or negotiation efficiency will result in financial profits for all users. The costs of heating and domestic hot water preparation are a significant component of the overall cost of the maintenance of flats in Poland. Therefore, it is even more important that the prices and rates agreed upon with the gas supplier are as favorable as possible to users. The high

$\bowtie$ Corresponding Author: Grzegorz Bartnicki; e-mail: grzegorz.bartnicki@pwr.edu.pl

${ }^{1}$ Department of Air Conditioning, Heating, Gas Supply and Air Protection, Wrocław University of Science and Technology, Poland; ORCID iD: 0000-0002-4482-6950; e-mail: grzegorz.bartnicki@pwr.edu.pl

2 Department of Air Conditioning, Heating, Gas Supply and Air Protection, Wrocław University of Science and Technology, Poland; ORCID iD: 0000-0002-9764-5555; e-mail: bogdan.nowak@pwr.edu.pl

2020. The Author(s). This is an open-access article distributed under the terms of the Creative Commons Attribution-ShareAlike International License (CC BY-SA 4.0, http://creativecommons.org/licenses/by-sa/4.0/), which permits use, distribution, and reproduction in any medium, provided that the Article is properly cited. 
costs of heat are not only expenses for apartment owners. The attractiveness of flat on the rental market is also decreasing. The business activity carried out in facilities located in such buildings is also less competitive.

The authors of the article analyzed gas prices on the Polish market over the last 3 years and presented the results of simulations of the effects of specific prices and rates set in the contract for the supply of fuel at the cost of heating from the point of view of a single apartment. As these are not large amounts per year, they do not motivate to optimize the terms of the gas purchase contract in this respect. The dynamics of changes in gas prices in Poland, although slightly different from world trends, is high. This makes it difficult for those responsible to make the decisions, and for residential users, it often means spending differences in subsequent years. One of the consequences of setting prices and rates significantly higher than obtainable may also be the reluctance of local communities to take measures to increase the energy efficiency of the heat supply system. From the point of view of heating costs, such decisions may distort the economic effect of thermo-modernization.

KEYWORDS: gas market, multi-family building, energy efficiency

\section{Introduction}

The creation of smart buildings and cities is aimed at improving the quality of life of their residents and protecting the natural environment. As highlighted in (Gungor et al. 2010) smart heat supply systems and smart buildings have optimized resource management, increase operational efficiency, ensure stable media supply, allow for real-time monitoring of system operations and enhance the possibilities of network reconfiguration and self-repair. All these directions require investments at the same time, and if they are financed from the owner's own resources, they are accompanied by the expectation of financial benefits (usually achieved in a short period of time). Expenses related to heating constitute a significant part of household maintenance costs, which increasingly, even in countries that are considered wealthy, result in the phenomenon of energy poverty (Galvin 2019). The reluctance to pay extra money is understandable, especially when a quick return on expenditure is not obvious. The relationship between energy efficiency and prices and low-carbon development strategies is described in (Bonatz et al. 2019). The authors indicate that difficulties in accessing investment funds limit interest in actions to improve energy efficiency and the use of renewable energy sources (RES), which leads to an increase in heat costs in the long run. Stala-Szlugaj (2019) indicates large changes in the coal sale price in 2010-2019. Coal prices in Poland follow the trend on international coal markets, although a time shift (by one year) is observed. From January 2010 to May 2019 the range of volatility prices of cubes from Polish coal mines fluctuated in the range of PLN 14-33/GJ, and in the case of imports within PLN 12-32/GJ. Regional diversity was also present. Price changes are also observed for other primary energy carriers. In households, this translates directly into the cost of purchasing fuel or the cost of purchasing heat generated from this fuel. However, three independent factors 
overlap with economic stability: energy prices, variability of heat consumption resulting from climatic conditions in subsequent heating seasons, and the effects of actions taken to improve energy efficiency and reduce fuel/energy consumption (and thus costs).

A significant part (about 55\%) of 14 million Polish households live in multi-family buildings. Buildings representing the resources of cooperatives or housing associations have a significant share in this group. Heat supply for these facilities is provided from the heating network or from local sources. In areas equipped with a gas network, heat supply from a gas boiler house (supplying part of the building, the entire building or a group of buildings with heat) was used even when access to the district heating network was available. In the case of using a gas-fired boiler house, to the signing and execution of a fuel supply contract is required for the operator. While a few years ago the gas market was fully monopolized and the terms of fuel supply were regulated, the admission of competition and the diversification of sources (possibility of purchase from various sellers) has recently resulted in high dynamics of price changes. Therefore, it is important that the prices and rates agreed with the gas fuel supplier are as favorable as possible to users. The period for which the contract is set is also important, as well as the terms of its termination (they determine the cost of concluding the contract on new terms before the end of the existing contract).

The excessively high costs associated with heat supply are not just additional expenses for flat owners. The attractiveness of residential premises on the rental market is also decreasing. This may also affect service activities in rented premises located in such resources, especially since the differentiation of such costs may even regard buildings next to each other.

\section{Gas market}

As of the October 1, 2017, the obligation to submit the tariffs for gas trading for approval to the President of the Energy Regulatory Office, set for all end users, except for household gas consumers, was waived. This was important for the development of competition in gas trading in Poland. Both fossil gas produced by individual member states and imported from outside the EU is available in the European Union. Gas combustion also has an increasing share in the emission of $\mathrm{CO}_{2}$, which indicates an increase in its use as a primary energy carrier. In view of the significant reduction of $\mathrm{CO}_{2}$ emissions, planned for 2050, a significant decrease in gas consumption in the EU should be expected in such a time perspective (Wyganowski 2020; Inman 2020). The European Commission's scenarios for achieving zero net emissions in 2050 predict that gas imports after 2030 in the EU will fall sharply (Wyganowski 2020; Report EC... 2019; Com EC... 2018). At the same time, the infrastructure for gas imports, transmission and use for energy purposes is further expanded (Inman 2020; Nace et al. 2019). The EU already has an excess gas infrastructure in relation to the needs and current gas consumption, and intends to develop it (Inman 2020). This situation on the gas market will favor customers because excess supply and 
competition will affect prices and offer favorable purchase conditions. It is also difficult to assess how these conditions will additionally be influenced by the effects of the COVID-19 pandemic but, as in the case of other energy carriers, a long-term impact on demand and price fluctuations is also expected.

From the point of view of the heat supply of residential buildings powered by local gas-fired boiler rooms, the decision on the choice of the gas supplier and the conditions of the contract concluded is made by the authorized bodies of the cooperative or housing association. The consequences of such decisions - mainly financial - are borne by the owners and users of residential premises. The manager's main goal is to guarantee the supply of heat to the building, and therefore the most important is to ensure the continuity of the contract for the supply of gas. Negotiations of the terms of the contract also boil down to determining the prices and rates applicable in a given period.

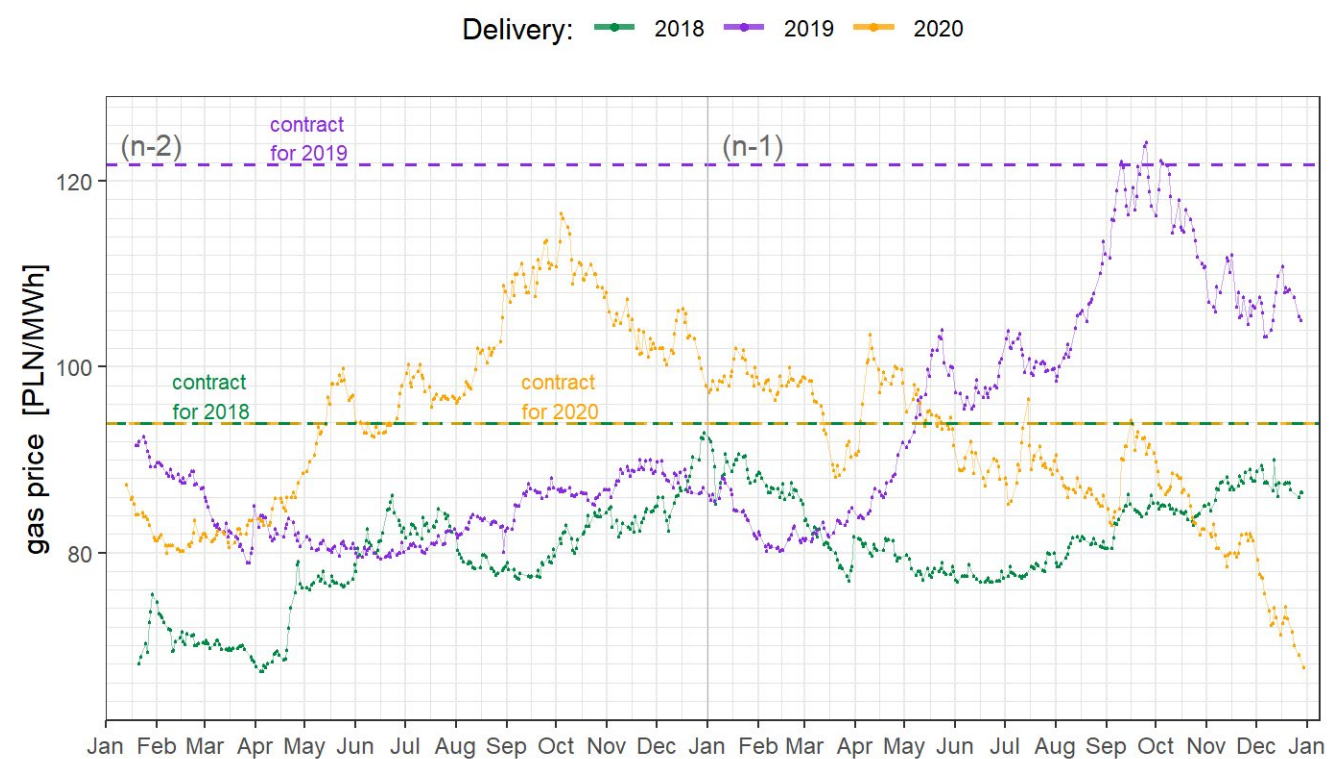

Fig. 1. Gas quotations on the delivery of the Polish Power Exchange (TGE) in forward contracts in terms of two (n-2) and one (n-1) years preceding the delivery date (delivery in 2018, 2019 and 2020) Source: own study based on the Polish Power Exchange (TGE)

Rys. 1. Notowania gazu na Towarowej Giełdzie Energii w kontraktach terminowych w ujęciu dwóch (n-2) oraz jednego roku (n-1) poprzedzającego termin dostawy (dostawa w 2018, 2019 i 2020 r.)

The entity making the decision about contracting fuel supplies for subsequent periods faces the difficulty of choosing the right moment to make such a decision. Classic analytical methods to support this decision are not always effective. This is due to the lack of many years of experience in the functioning of the gas market under new formal conditions as well as gas fluctuations that are difficult to predict. Considering the decrease in supply during the period 
of reduced heat demand in the summer, fuel prices should be expected to lower in the summer than in the spring and autumn. Figure 1 presents gas quotations on the Polish Power Exchange (TGE in forward contracts in terms of two and one years preceding the delivery date. In 2016-2020 , the reduction of prices in the summer period occurred only in May-August 2017 for fuel deliveries in 2018. For supplies for 2019, gas prices were the highest in the period from September-December 2018. In 2019, there were also decreases in gas prices as a consequence of geostrategic changes and therefore price changes were much greater than those related to risk discounting. Another problem may be the period for which the contract is concluded. The purchase of fuel 2 years in advance is associated with greater risk than a transaction executed only one year in advance. Consequently, it should be expected that prices for deliveries carried out in 2 years may be higher than for deliveries carried out in the following year. In this way, the seller would discount the risk arising from the transaction over a much longer period of time and the more likely possibility of a difference between the forecasts and the actual conditions. At the same time, however, it ensures the seller's collection of fuel in the long term.

It should be reckoned with that persons responsible for managing housing resources are most often not experts in the gas market. Therefore, it is difficult for them to make optimal decisions and conduct effective negotiations with suppliers. Therefore, they benefit from support provided by consultants or account managers seconded by gas trading companies. This consultant primarily represents the seller. In the case of the heat supply system which is the subject of the analysis (in order to determine the terms of fuel supply in the next calendar or gas year, i.e. October-September), the consultant made contact at fairly characteristic moments, from the point of view of price conditions on the gas market. Considering gas quotations on the Polish Power Exchange in forward contracts on Figure 2, they indicate periods in which a sales consultant contacted the boiler house operator. As you can see, this was usually the moment of the price increase. Based on the time proposed by the consultants to determine the terms of fuel delivery, the purchaser had no possibility to negotiate a more favorable price, even if it was even close to the lowest possible. The pressure of the need to ensure the heat supply and the lack of direct financial consequences for the property manager (cost transferred to heat users) leads to the acceptance of the rules offered by the seller. From the point of view of a single heat consumer, these are not large differences in monthly fees. However, this translates into an annual cost of operation of the heat source. Therefore, the need for an in-depth impact analysis is justified from the point of view of those who make such decisions, as well as an assessment of how important this problem is. The study was conducted for a housing community (WM), whose buildings are supplied with heat from a local gas boiler house, located in Wrocław. It includes 4 buildings, each on a rectangular plan which are 4 storeys high. There are a total of 254 residential premises and 2 commercial premises in the buildings. The heat supply system consists of two gas boiler houses, each supplying two buildings. Each boiler house has two gas boilers (without condensation) and a battery of 3 hot water heaters with a total capacity of $1500 \mathrm{dm}^{3}$. 


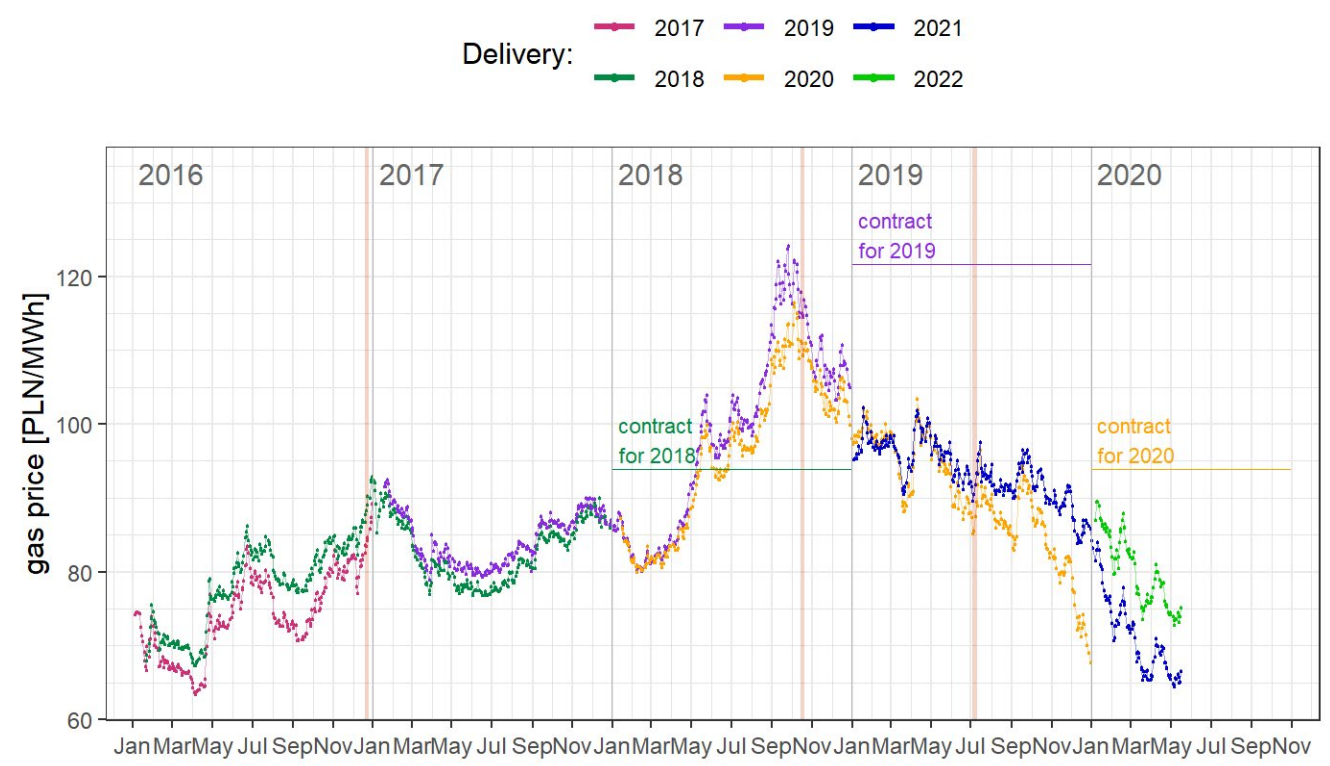

Fig. 2. Deadlines for contacting a sales consultant with the operator of the analyzed heat supply system considering gas quotations on the Polish Power Exchange (TGE) in forward contracts. The prices agreed in subsequent gas sales contracts were also marked

Source: own study based on the Polish Power Exchange (TGE)

Rys. 2. Terminy skontaktowania się doradcy handlowego z operatorem analizowanego systemu zaopatrzenia w ciepło na tle notowań gazu na Towarowej Giełdzie Energii w kontraktach terminowych. Zaznaczono też ceny uzgodnione

w kolejnych umowach na sprzedaż gazu

\section{Heat costs in property maintenance expenses}

Expenses related to the purchase of fuel are a very important element in the budget of the analyzed housing community. In 2016-2019, this share varied from 32.9 to $36.9 \%$. It was at almost the same level, despite changing climatic conditions in subsequent years or differences in the community budget for other items. The supply of heat to residential premises (heating and domestic hot water preparation) is also a much higher financial burden compared to other components of property maintenance costs, which are often considered more important, and in the broad public perception, are considered to be much more costly (maintaining cleanliness, renovations, infrastructure of building surroundings). Figure 3 presents the share of costs of heat supply and other costs of maintaining the property in the analyzed housing community in 2016-2019 (a) and for another community that manages a group of buildings in the neighborhood (b). 
a.

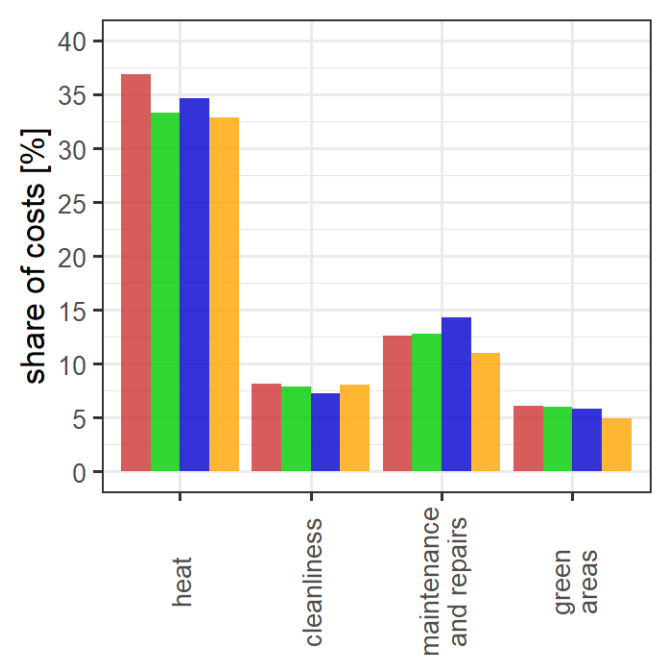

b.

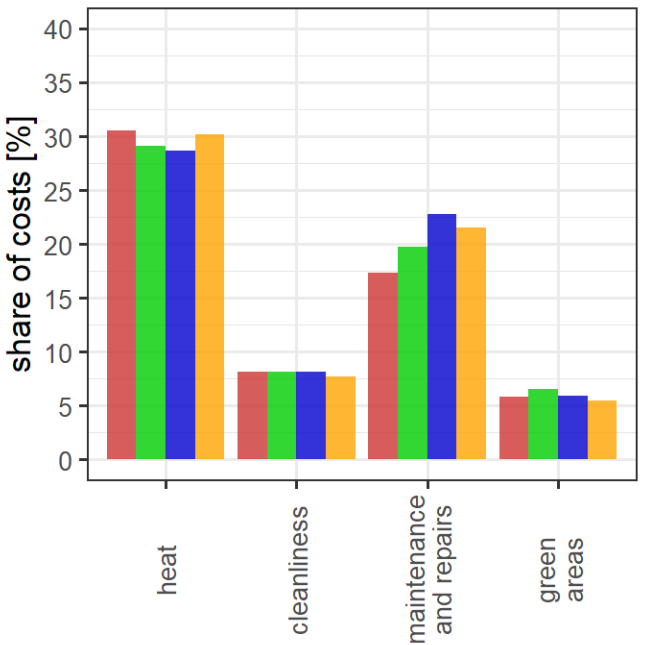

Fig. 3. The share of costs of heat supply and other costs of maintaining the property in the analyzed housing community (a.) and for another community that manages a group of buildings in the neighborhood community (b.) in 2016-2019

Source: own study

Rys. 3. Udział wydatków w wybranych działach planu gospodarczego dla badanej wspólnoty mieszkaniowej (a.) oraz dla porównania w sąsiedniej nieruchomości (b.) w latach 2016-2019

The increase in the unit price in 2019 by more than $78 \%$ compared to the base year (2016) resulted in only a $12 \%$ increase in the total gas purchase costs (Fig. 4). Such an effect resulted, among others, from the fact that the total cost of heating depends at the same time on fuel consumption resulting from weather conditions in a given year and hot water consumption. Therefore, it is easy to explain to heat consumers that high heating costs are not so much the result of contractual conditions as weather conditions and unreasonably high consumption of hot water. People responsible for managing the property of housing associations and cooperatives are aware of how difficult it is to prove their responsibility for wrong fuel purchase decisions. They are also often unaware of how much expenditure could be reduced if better sales contract conditions were provided. Due to the lack of current knowledge, residents (who bear the heating costs) are not aware of the conditions of gas purchase and may even think that the purchaser has no influence on the price of gas (based on their knowledge of the purchase conditions for individual consumers or the state of affairs at the time when prices were regulated). Such conditions, and, above all, the lack of a clear relationship between the change in the unit price of gas and the total expenditure related to annual heat costs mean that the pressure to take action to obtain the best possible contractual conditions when purchasing gas disappears. When discussing various conditions for the problem under analysis, attention should also be paid to the increasingly conscious 
planning of maintenance costs by flat owners, especially within housing associations. The expenditure plan prepared for the property at the beginning of the financial year and assuming an increase in heat expenditure (increase in costs) encourages the residents of this community to take actions to reduce expenses (by reducing the consumption of heat and hot water). This is another random variable factor that, together with other factors, affects the annual cost of heat. Figure 4 presents the increase in the gas purchase cost for the needs of the boiler house supplying heat to the buildings of the housing community in relation to the change in the unit price of gas. The reference level is the prices in 2016. The cost of purchasing fuel increased much slower in the analyzed period than the unit gas prices. Relatively warm winters, actions taken by the property manager to improve the energy efficiency of the heat supply system, or heat consumption reduced by residents themselves (thus minimizing the cost of using the premises) limited this increase. It should also be pointed out that in 2019 the weather conditions at the turn of April and May caused an extension of the heating season by an entire month, additional heat consumption for heating flats and a significant reduction in the efficiency of the heat supply system in May 2019 (Bartnicki et al. 2020).
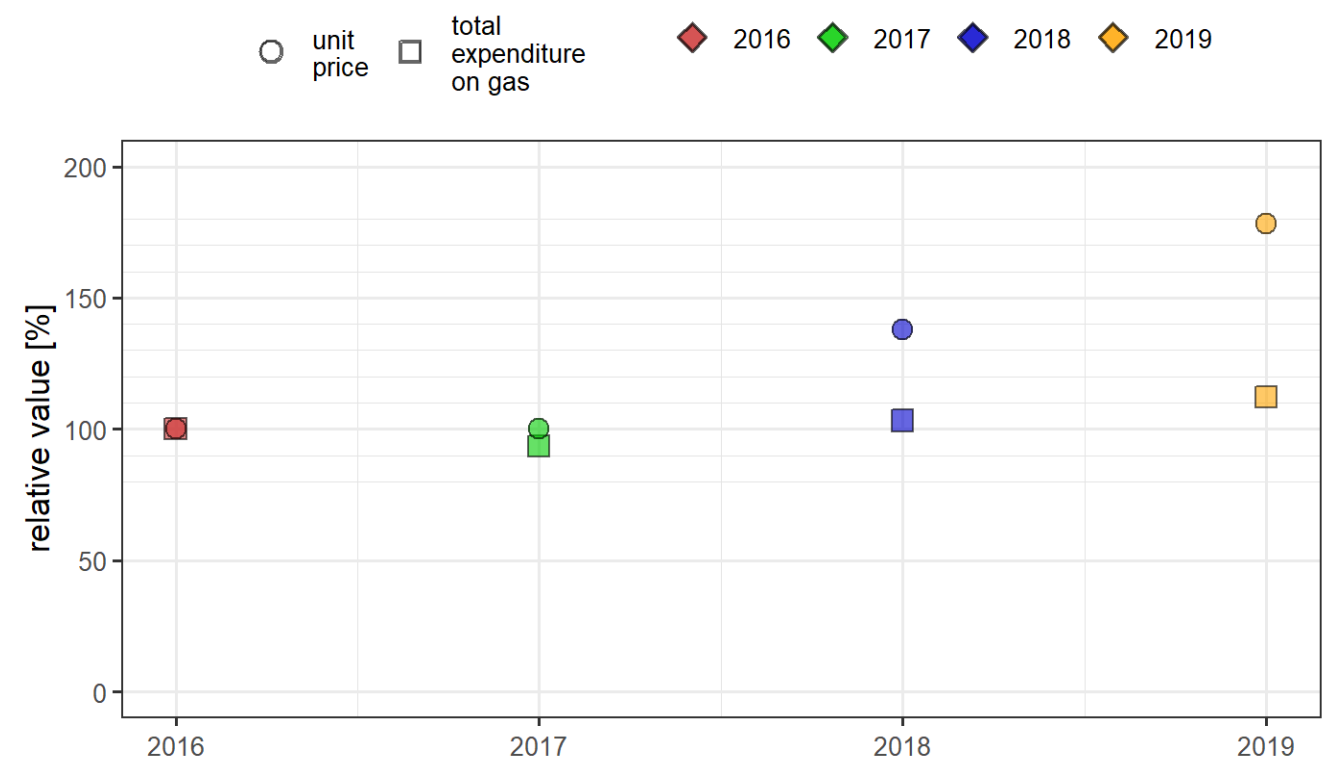

Fig. 4. Change in the unit price of gas and total expenditure on gas purchase compared to the base year $(2016-100 \%)$ Source: own study

Rys. 4. Zmiana ceny jednostkowej gazu oraz całkowitych wydatków na zakup gazu. 2016 - rok bazowy (100\%) 


\section{Impact of gas price on heating costs}

The analysis was carried out for 2019. Gas prices have fallen this year (Fig. 2), which was not provided for in contracts concluded well in advance. The costs of purchasing fuel for heat production in the local gas boiler house must be incurred entirely by end users. In accordance with the common practice applied by housing cooperatives and associations, the total costs are therefore divided into fixed and variable costs, separately for space heating and hot water preparation.

In 2019, fuel consumption in two boiler houses of the housing community amounted to $192,247 \mathrm{~m}^{3}$, i.e. $2,138,391 \mathrm{kWh}(7,692.1 \mathrm{GJ})$. Total heat consumption (based on the indications of residential heat meters) amounted to $2,773.5$ GJ. Total hot water consumption (at $\left.55^{\circ} \mathrm{C}\right)$ amounted to $8,758.40 \mathrm{~m}^{3}$ (based on readings of residential water meters, which corresponds to 1,467.9 GJ (with heating by $40 \mathrm{~K}$ ). As part of the analysis, two simulations were made regarding the possible (hypothetical) total costs of fuel purchase and other factors related to the settlement of heat costs, taking the current prices into account. On the basis of quotations on the Polish Power Exchange (Commodity Forward Instruments Market) the lowest and the highest possible rate for gas with delivery for 2019 was determined. The price for the end user additionally includes the seller's margin and such a margin was included in the adopted rate for the "Lowest price" scenario and the "Highest price" scenario. Comparing offers submitted by suppliers over the last 4 years, it has been assumed that the prices offered are higher by approx. $10 \%$ from quotations on the Polish Power Exchange during this period. In the period 2016-2019, negotiated terms of fuel delivery were closer to the highest recorded rate than to the most favorable conditions for the recipient. With the adopted unit price assumptions for both mentioned scenarios, the simulation results are summarized in Table 1.

TABLE 1. Comparison of the main measures for the three scenarios considered for 2019

TABela 1. Porównanie głównych mierników dla trzech rozpatrywanych scenariuszy dla $2019 \mathrm{r}$.

\begin{tabular}{|l|c|c|c|}
\hline & $\begin{array}{c}\text { Scenario } \\
\text { Real expenses }\end{array}$ & $\begin{array}{c}\text { Scenario } \\
\text { Lowest price }\end{array}$ & $\begin{array}{c}\text { Scenario } \\
\text { Highest price }\end{array}$ \\
\hline Total fuel consumption $\left[\mathrm{m}^{3}\right]$ & 192,247 & 192,247 & 192,247 \\
\hline Fuel unit price (net) $\left[\mathrm{PLN} / \mathrm{m}^{3}\right]$ & 0.12170 & 0.08814 & 0.13650 \\
\hline Total fuel purchase costs (gross) [PLN] & $388,605.62$ & $319,764.65$ & $446,951.61$ \\
\hline Share of fixed costs [\%] & 11.6 & 14.1 & 10.1 \\
\hline Costs settled from the premises area [PLN] & $148,142.61$ & $127,490.31$ & $165,646.40$ \\
\hline $\begin{array}{l}\text { The cost settled based on the indications of housing } \\
\text { devices (water meters and heat meters) [PLN] }\end{array}$ & $240,463.02$ & $192,274.33$ & $281,305.21$ \\
\hline Unit cost of space heating (per $\mathrm{m}^{2}$ ) [PLN] & 55.73 & 44.56 & 65.20 \\
\hline $\begin{array}{l}\text { Unit cost of domestic hot water preparation }\left(\mathrm{per}^{3} \text { ) }\right. \\
\text { [PLN] }\end{array}$ & 9.81 & 7.84 & 11.47 \\
\hline
\end{tabular}

Source: own study. 
Total expenditure on the purchase of fuel in the "Highest price" scenario is $15.0 \%$ higher than actually incurred (i.e. the "Real expenses" scenario). A contract with the lowest price would, on the other hand, give expenses representing $82.29 \%$ of the costs actually incurred in 2019. The lowest price is $72.42 \%$ of the price from the "Real expenses" scenario, while the highest price is $12.16 \%$ higher than actually calculated on based on the contract applicable for 2019.

A simulation of the settlement for heating of the residential premises was also carried out for the proposed scenarios. At the same time, the details resulting from individual formal and legal conditions affecting the volume of the given premises' share in common areas were omitted. The simulations were performed for three cases using the same rules in order to ensure the possibility of formulating conclusions. The results of this analysis are presented in the form of a histogram (Fig. 5). The "Lowest price" scenario results in savings from PLN 66.68 to PLN 411.45 per residential premises per year, and in the case of one premises even savings of PLN 611.39. In the case of calculations for the "Highest price" scenario, the increase in heating costs ranges from PLN 56.52 to PLN 348.73, and in the case of one residential premises it would amount to as much as PLN 518.19. All values were estimated annually, relative to the actual fuel supply contract.
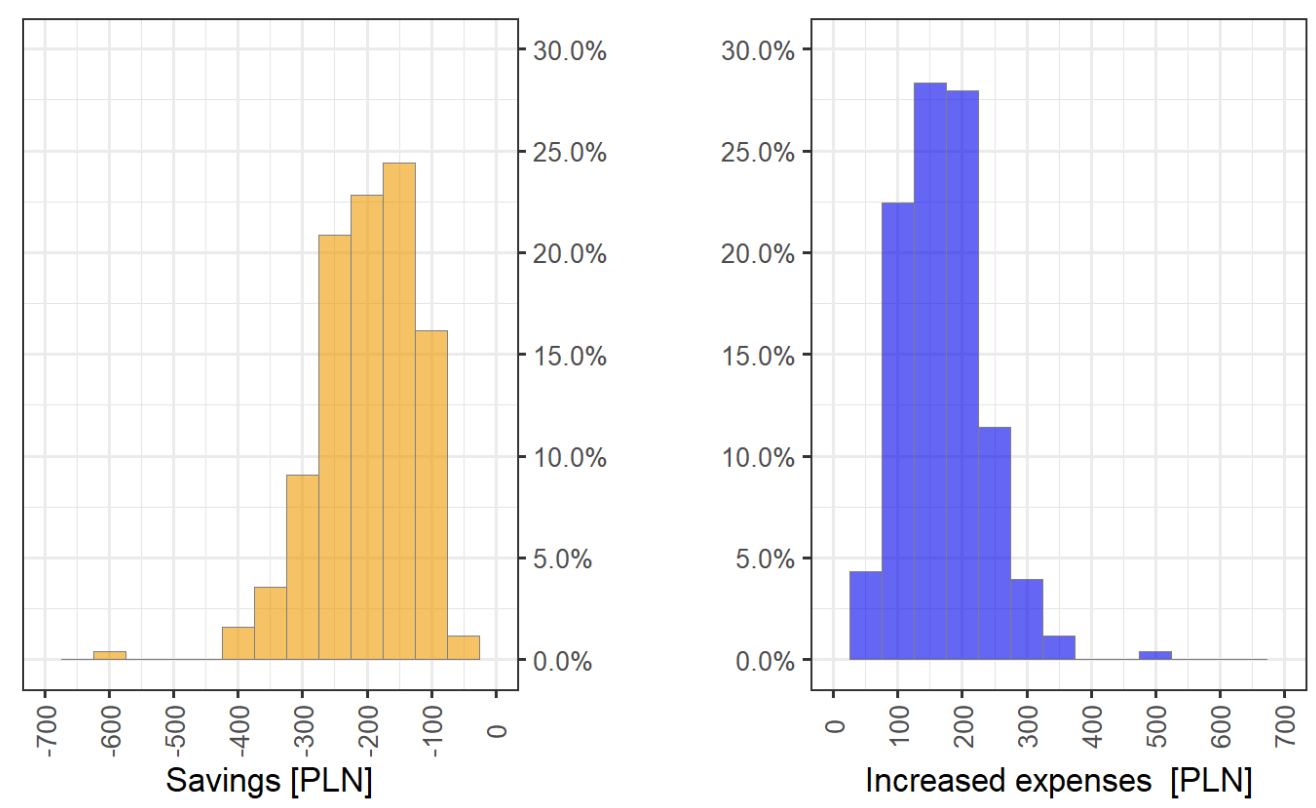

Fig. 5. Potentially savings and increased expenses for heating of the residential premises. The "Lowest price" scenario and the "Highest price" scenario in 2019 Source: own study

Rys. 5. Potencjalne oszczędności oraz podwyższone wydatki za ogrzewanie pomieszczeń w lokalach mieszkalnych w scenariuszu „Najniższa cena” oraz „Najwyższa cena” dla 2019 r. 
The change in the annual costs of space heating is strongly associated with the consumption of heat, and, to a much lesser extent, with the size of the residential premises. This is illustrated in Figure 6. This is due to the fact that the component of heating costs calculated as a function of the share of a given premises in common areas depends on fuel prices to a small extent. In housing cooperatives or associations where the regulations for settling heat costs include an increased share of the so-called fixed charges (independent of heat meter indications and settled e.g. on the basis of the usable floor area of the premises or shares in the property), the above described dependence may not occur.

In the scope of changes in costs incurred for preparing domestic hot water, the amounts are already smaller.
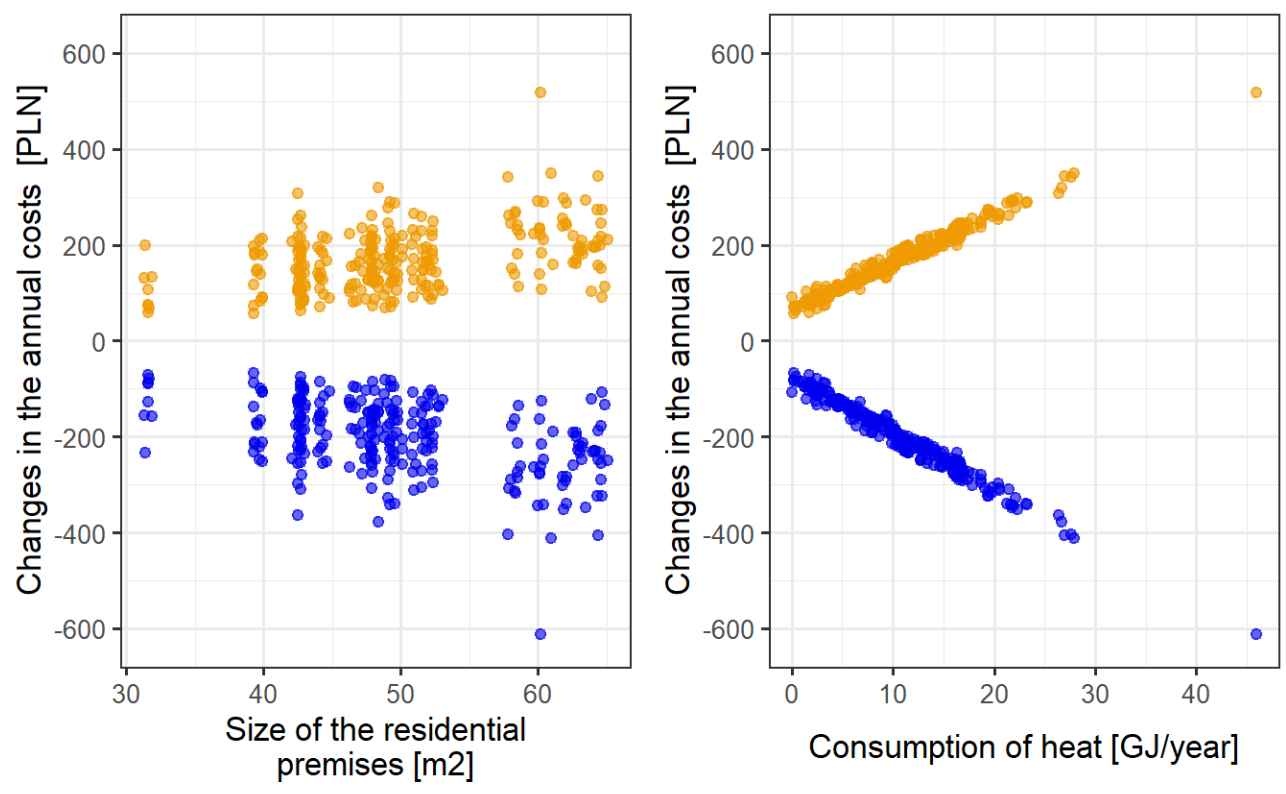

Fig. 6. The changes in the annual costs of space heating depending on the size of the residential premises and consumption of heat Source: own study

Rys. 6. Wielkość zmiany kosztów za ogrzewanie pomieszczeń w zależności od powierzchni lokalu mieszkalnego oraz rocznego zużycia ciepła

In the "Lowest price" scenario, the average saving is PLN 67.53 per year for a single residential premises. In the case of $90 \%$ of premises supplied with heat, the savings would not exceed PLN 125. Expenditures would increase by PLN 57.24 per year on average in the alternative scenario. For $95 \%$ of residential premises supplied with heat, expenditures would not increase by more than PLN 120 (per year). The total (space heating and hot water preparation) savings and increase in expenses were also compared. The "Lowest price" scenario for $90 \%$ of residential 

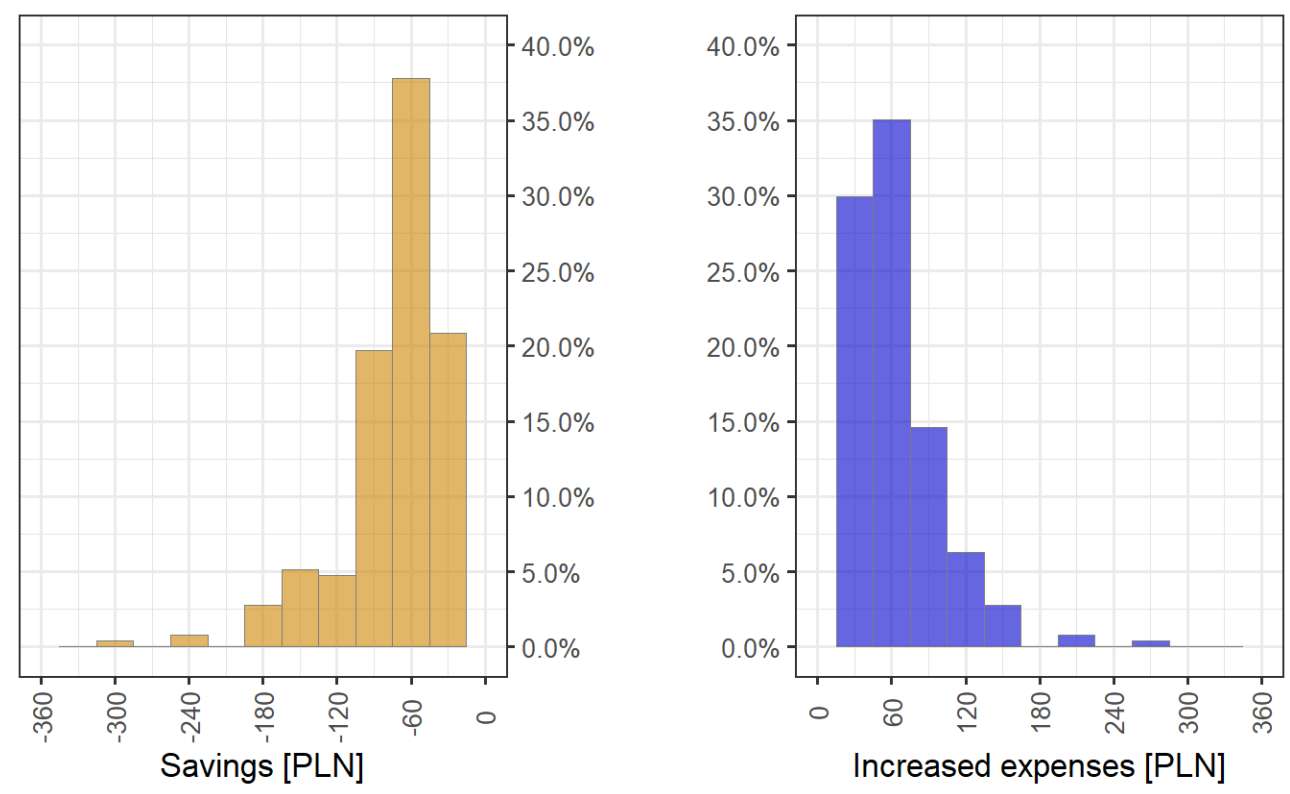

Fig. 7. Potentially saving and increased expenses for preparing domestic hot water in premises. The "Lowest price" scenario and the "Highest price" scenario in 2019

Source: own study

Rys. 7. Potencjalne oszczędności oraz podwyższone wydatki na przygotowanie c.w.u. w lokalach mieszkalnych w scenariuszu „Najniższa cena” oraz „Najwyższa cena” dla 2019 r.

TABLE. 2. Comparison of the main measures for the two scenarios considered in 2019

TABELa 2. Porównanie głównych mierników dla trzech rozpatrywanych scenariuszy dla 2019 r.

\begin{tabular}{|l|c|c|}
\hline \multicolumn{1}{|c|}{ Scenario } & „Lowest price” scenario & „Highest price” scenario \\
\hline Minimal change [PLN] & 82.18 & 69.65 \\
\hline Maximum change [PLN] & 660.41 & 559.73 \\
\hline Average change [PLN] & 268.68 & 227.72 \\
\hline Median change [PLN] & 262.64 & 222.60 \\
\hline
\end{tabular}

Source: own study.

premises results in total savings of no more than PLN 380 (per year). In the case of the "Highest price" scenario, 90\% of the premises would not incur expenses exceeding PLN 325 (per year).

Based on the calculated increase in expenses for heating, as well as those related to hot water preparation, taking the total increased expenses and the area of the flat into account, four clusters (groups) of flats were distinguished, i.e. (1) a slight increase in costs, (2) a noticeable increase in costs, (3) large increase in costs and (4) very large increase in costs. Figure 8 presents points 
corresponding to flats belonging to particular clusters in the coordinate system: change in heating costs and change in the costs of hot water preparation for the "Highest price" scenario.

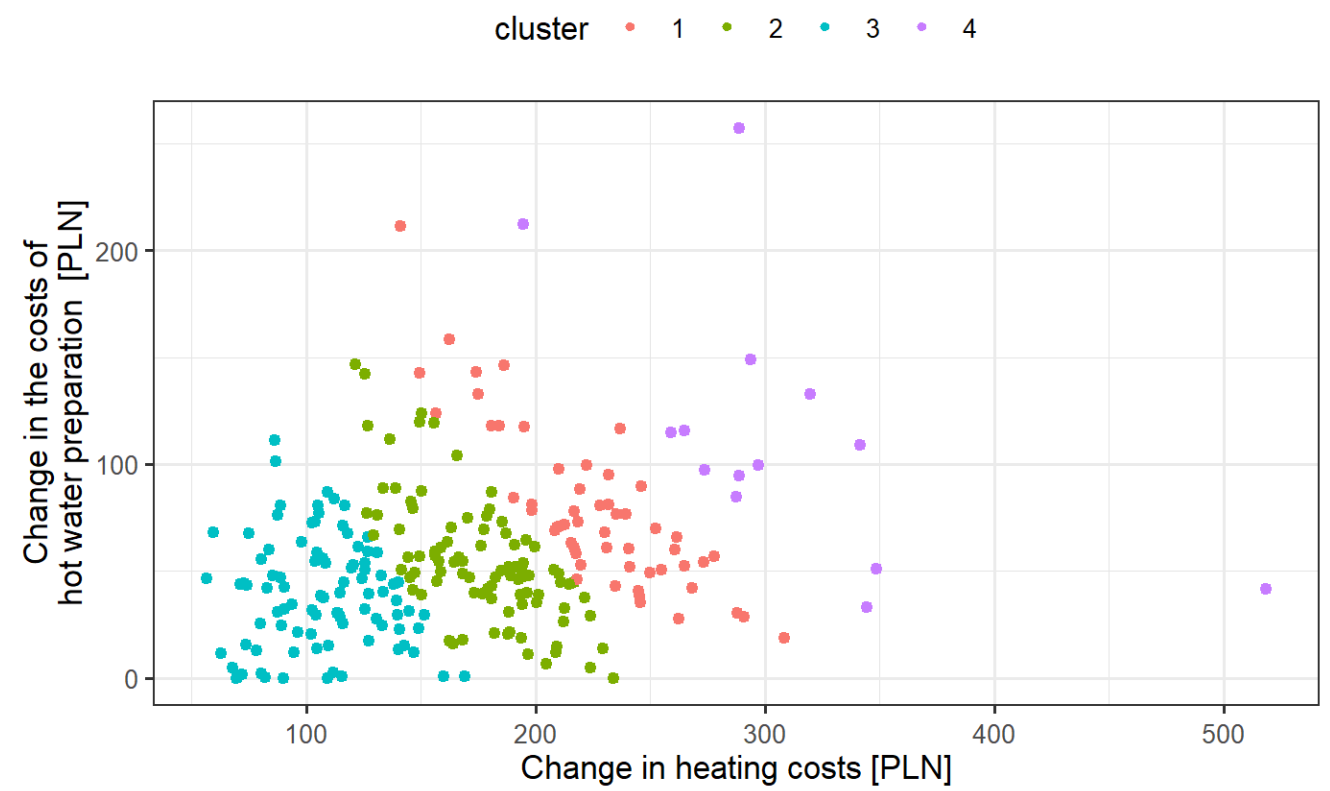

Fig. 8. The relationship between the change in heating costs and change in the costs of hot water preparation divided into four clusters (groups) of flats (k-means) for the "Highest price" scenario in 2019

Source: own study

Rys. 8. Relacja pomiędzy podwyższonymi kosztami na ogrzewanie pomieszczeń i przygotowanie c.w.u. w podziale na 4 grupy odbiorców (k-means) dla scenariusza „Najwyższa cena” dla 2019 r.

\section{Financial consequences for the premises}

The calculations carried out for two variants show that the change in price conditions regarding gas supply gives a difference in the cost of heat at the level of several hundred zlotys per flat per year. It happens that with such a level of the disputed amount of the annual settlement for heat, tenants question the fee charged by the administrator, settling the dispute in court. The costs of such proceedings exceed the amount of the dispute many times, which is therefore more ambitious rather than financial. There is also no formal basis for the resident to question the gas supply contract itself. The results of the analysis show that there is no incentive for the property manager (from the level of residents) to make decision-making efforts for tough negotiations with fuel suppliers. As the calculations shown in Table 1, the difference in the total cost of buying fuel is already approx. PLN 70 thousand. This amount would be distributed over time to all the 
premises, but from the point of view of the budget of the property this is already a significant amount. Negotiations on the conditions of fuel purchases, and in particular the choice of time to start them, require a lot of expertise, skills and experience (usually a belief in the weaker negotiating position of the purchaser is dominant). In addition, attention should be paid to other key provisions that decide on other than pricing terms of delivery, e.g. the form of settlement (payment based on the forecast) or the conditions and form of submitting complaints.

It should also be remembered that, to a significant extent, the role of the housing community comes down to the role of "treasurer", i.e. calculating, collecting and aggregating funds from individual owners. The bodies of housing associations and cooperatives show that the costs of space heating and hot water preparation are the result of external entities' activities without a significant role of the internal bodies of the property manager.

An important threat expressed by decision-makers is also the high probability of marginalizing the workload in negotiating lower prices by weather conditions. Low external temperatures in the winter period, increased consumption of hot water make the public perception of high costs, and the work of people involved in setting price conditions is not only unnoticed but often questioned. This reasoning also leads to a reduction in activities aimed at reducing heat consumption. In this case, there is an additional risk that the implemented projects will not bring the expected effect, and the only real effect will be spending additional financial funds.

\section{Summary and conclusions}

Taking decisions or creating reference measures based solely on cost and financial indicators can lead to wrong decisions, or at least to postponing them. This context is particularly important for organizations and entities in which key decisions must be made in a collective way. In the case of housing associations, decisions that go beyond the so-called 'ordinary management' are taken by resolution by all members of the community. Extremely often the key argument influencing the final decision of individuals who are not experts are financial conditions and the minimization of costs incurred. When considering and later recommending decisions on specific projects, the authorities take into account the risk that the financial effect of potentially energy-efficient activities will be suppressed or even reversed by weather conditions or price conditions in subsequent years. Projects increasing energy efficiency are characterized by a simple payback period of several to several years. With a high variability of weather (Bartnicki at al. 2020) and price conditions, it may be difficult to settle such projects before members of a housing association or cooperative. This results in a lack of such risk being taken by the property management boards, all the more so because it requires their additional involvement and exposes them to charges.

The high dynamics of changes in the gas market (which may still be continued in the future) combined with deep changes in the heat market make it very difficult for decision-makers to 
make decisions on changing the way of supplying. In terms of financial consequences, each decision is also burdened with a high risk of incurring higher expenses than the alternative. Therefore, leaving the status quo is a socially acceptable option. A bottom-up initiative is unlikely to be a bottom-up initiative that would also cover the majority of of residents. In light of these conditions, optimization of the heat supply system in terms of costs and $\mathrm{CO}_{2}$ emissions is impossible (Palej et al. 2019). In the case of heat sources using gas as a fuel, it is also pointless to forecast accumulated costs over a period of 10-15 years. Therefore, new methods of economic analysis should be developed for thermomodernization investments where temporary (current) fuel prices will not be taken into account. Otherwise, the theoretically calculated effects will later deviate from the actually achieved effects. It may be advisable to develop and implement a group of indicators which will motivate such organizations as housing associations or cooperatives to undertake activities aimed at reducing fuel consumption and environmental impact. (Dell'Isola et al. 2018) pointed out the difficulties in making decisions by the entire community of flat owners and the need to use special financial mechanisms that are intended to encourage activities related to improving energy efficiency. The awareness that choosing a solution that is beneficial in terms of reducing expenses is extremely difficult may lead to organizations such as housing associations to abandon activities until the equipment is used up. After that time, the decision on new solutions will come down to choosing the system with the lowest investment costs.

It is also worth noting that the cost of space heating or hot water preparation, even if determined as a unit size (per $\mathrm{m}^{2}$ and $\mathrm{m}^{3}$ ) is not representative. They depend on so many factors (including random ones) that it is impossible to determine the influence of individual components on the final value without in-depth analysis.

\section{References}

BARTNICKI, G. and NowaK, B. 2020. The end of the heating season versus the energy efficiency of the heating installation (Koniec sezonu grzewczego a efektywność energetyczna instalacji odbioru ciepła). Instal Vol. 416, Iss. 4, pp. 2-11, DOI: 10.36119/15.2020.4.1 (in Polish).

Bonatz et al. 2019 - Bonatz, N., Guo, R., Wu, W. and LiU, L. 2019. A comparative study of the interlinkages between energy poverty and low carbon development in China and Germany by developing an energy poverty index. Energy and Buildings 183, pp. 817-831, DOI: 10.1016/j.enbuild.2018.09.042.

COM EC... 2018. Communication from the Commission to the European Parliament, the European Council, the Council, the European Economic and Social Committee, the Committee of the Regions and the European Investment Bank, A Clean Planet for all. A European strategic long-term vision for a prosperous, modern, competitive and climate neutral economy. Brussels 28.11.2018 r. COM(2018) 773 final.

Dell'Isola et al. 2018 - Dell'Isola, M., Ficco, G., Canale, L., Frattolillo, A. and Bertini, I. 2018. A new heat cost allocation method for social housing. Energy and Buildings 172, pp. 67-77, DOI: 10.1016/j.enbuild.2018.05.004.

Galvin, R. 2019. Letting the Gini out of the fuel poverty bottle? Correlating cold homes and income inequality in European Union countries. Energy Research \& Social Science Vol. 58, DOI: 10.1016/j. erss.2019.101255. 
Gungor et al. 2010 - Gungor, V.C., Lu, B. and Hancke, G.P. 2010. Opportunities and challenges of wireless sensor networks in smart grid. IEEE Trans. Ind. Electron. 57, pp. 3557-3564.

Inman, M. 2020. Gas at a Crossroads. Global Energy Monitor. February 3. [Online] https://globalenergymonitor.org/reports/ [Accessed: 2020-04-24].

Nace et al. 2019 - Nace, T., Plante, L. and Browning, J. 2019. The New Gas Boom: Tracking Global LNG Infrastructure. Global Energy Monitor. July 1. [Online] https://globalenergymonitor.org/reports/ [Accessed: 2020-04-24].

Palej et al. 2019 - Palej, P., Qusay, H., Kleszcz, S., Hanus, R. and Jaszczur, M. 2019. Analysis and optimization of hybrid renewable energy systems. Polityka Energetyczna - Energy Policy Journal Vol. 22, Iss. 2, pp. 107-120, DOI: 10.33223/epj/109911.

Report EC... 2019. Report from the Commission to the European Parliament and the Council, Preparing the basis for increasing long-term ambitions, Progress report on EU climate action in 2019. Brussels, 31.10.2019 r. $\operatorname{COM}(2019) 559$ final.

Stala-Szlugaj, K. 2019. Analysis on a regional basis of trends in hard coal prices for Polish households. Polityka Energetyczna - Energy Policy Journal Vol. 22, Iss. 3, pp. 57-70, DOI: 10.33223/epj/112086.

Wyganowski, J. 2020. EUR 120 billion for gas investments in Europe (120 mld euro na inwestycje gazowe w Europie). Energia Gigawat 1-2. [Online] https://rynek-gazu.cire.pl/st,43,298,item,193734,2,0,0,0,0,0,120-mld-euro-na-inwestycje-gazowe-w-europie.html [Accessed: 2020-02-17] (in Polish).

Grzegorz BARTNICKI, Bogdan NowAK

\title{
Rynek paliw gazowych w Polsce a koszty końcowej energii cieplnej wytwarzanej w kotłowni lokalnej
}

\author{
Streszczenie
}

Znaczna część (około 55\%) z ponad 14 mln polskich gospodarstw domowych stanowi fragment budynków wielorodzinnych. W tej grupie duży udział mają budynki będące zasobami spółdzielni lub wspólnot mieszkaniowych. Zaopatrzenie w ciepło odbywa się z sieci ciepłowniczej lub ze źródeł lokalnych. W odniesieniu do obiektów, które są zasilane z kotłowni gazowych, konieczne jest podpisanie i realizacja umów na dostawę gazu. Od 1 października 2017 r. został zniesiony obowiązek przedstawiania do zatwierdzenia Prezesowi Urzędu Regulacji Energetyki taryf w zakresie obrotu gazem, z wyjątkiem odbiorców w gospodarstwach domowych. Decyzje w zakresie wyboru dostawcy i treści zawieranej umowy podejmują uprawnione do tego organy spółdzielni lub wspólnoty mieszkaniowej. Konsekwencje takich decyzji ponoszą użytkownicy lokali mieszkalnych. Umowa na dostawę paliwa gazowego ustala ceny i stawki obowiązujące w danym okresie. Trafność decyzji o momencie zawarcia lub aneksowania umowy, wypowiedzenia dotychczasowych warunków i podpisanie nowej umowy czy też skuteczność negocjacyjna skutkują obciążeniem finansowym dla wszystkich użytkowników, a przecież koszty ogrzewania pomieszczeń i przygotowania ciepłej wody użytkowej stanowią w Polsce znaczącą składową ogólnych kosztów utrzymania 
nieruchomości. Zbyt wysokie koszty związane z zaopatrzeniem $\mathrm{w}$ ciepło to nie tylko dodatkowe wydatki dla właścicieli mieszkań. Zmniejsza się również atrakcyjność lokali mieszkalnych na rynku najmu. Prowadzona działalność usługowa w lokalach usługowych zlokalizowanych w takich zasobach jest również mniej konkurencyjna.

Autorzy artykułu przeanalizowali ceny gazu na polskim rynku w okresie ostatnich 3 lat i przedstawili wyniki symulacji skutków określonych cen i stawek ustalonych w umowie na dostawę paliwa na koszt ogrzewania z punktu widzenia pojedynczego lokalu. Ponieważ w skali roku nie są to duże kwoty, nie motywują one do optymalizacji w tym zakresie warunków umowy na zakup gazu. Dynamika zmian cen gazu w Polsce, mimo że nieco odbiegająca od trendów światowych, jest duża. Utrudnia to osobom odpowiedzialnym podejmowanie trafnych decyzji, a dla użytkowników lokali mieszkalnych często oznacza różnice wydatków w kolejnych latach. Jedną z konsekwencji ustalenia cen i stawek istotnie wyższych od możliwych do uzyskania może być też niechęć lokalnych społeczności do podejmowania działań zwiększających efektywność energetyczną systemu zaopatrzenia w ciepło. Z punktu widzenia kosztów ogrzewania takie decyzje mogą bowiem wypaczyć efekt ekonomiczny termomodernizacji.

SŁOWA KLUCZOWE: rynek gazu, budynek wielorodzinny, efektywność energetyczna 
